Témoigner Témoigner. Entre histoire et mémoire

Getuigen Revue pluridisciplinaire de la Fondation Auschwitz

$121 \mid 2015$

Violences radicales en scène

\title{
Censorship under the Franco regime
}

\section{Guillermo Sanz Gallego}

\section{(2) OpenEdition}

\section{Journals}

Electronic version

URL: https://journals.openedition.org/temoigner/3512

DOI: 10.4000/temoigner.3512

ISSN: 2506-6390

\section{Publisher:}

Éditions du Centre d'études et de documentation Mémoire d'Auschwitz, Éditions Kimé

Printed version

Date of publication: 1 October 2015

Number of pages: 172

ISSN: 2031-4183

\section{Electronic reference}

Guillermo Sanz Gallego, "Censorship under the Franco regime", Témoigner. Entre histoire et mémoire [Online], 121 | 2015, Online since 01 October 2016, connection on 03 February 2022. URL: http:// journals.openedition.org/temoigner/3512 ; DOI: https://doi.org/10.4000/temoigner.3512

This text was automatically generated on 3 February 2022.

Tous droits réservés 


\title{
Censorship under the Franco regime
}

\author{
Guillermo Sanz Gallego
}

1 The Franco regime enforced a strong censorship policy. On 22 April 1938, one year before the Spanish Civil War came to an end, the Ley de Prensa was signed by Ramón Serrano Suñer, who was Franco's brother-in-law and, at the time, the Nationalist Minister of the Interior. The law remained in effect nearly 30 years and served as a form of political propaganda. Four main censorship criteria were used: political opinions, religion, sexual morality, and use of language. Writers were not allowed to express any criticism against Francoism, its ideology, its ideologues, its accepted historiography, or its laws. Criticism of Catholicism was not permitted. References to abortion, divorce, adultery, and homosexuality were forbidden, and published work could not contain taboo language or a register that could be considered obscene or indecent. By applying this censorship law, the Franco regime intended to "ensure both the dissemination of truth and the work of national reconstruction" (Foreword to the Normas generales, 1944). In fact, the policy reveals the regime's efforts to control cultural expression and repress dissident political views. 
Template for censors dating from the Ley Fraga era

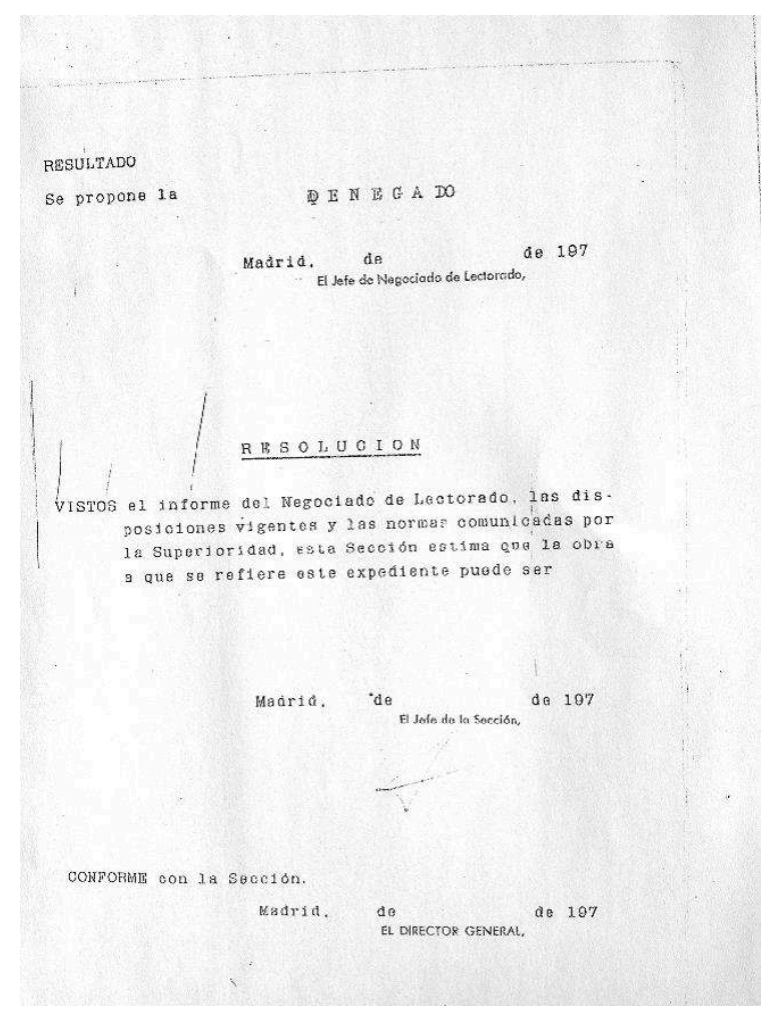

(c) GSG

2 A new law, the Ley de Prensa e Imprenta, was enacted on 18 March 1966. It was commonly called Ley Fraga because it was signed during Manuel Fraga's term as Minister of Information and Tourism. This law was in theory less rigid and it implied a first step toward freedom of speech. Henceforth preventive censorship was abolished. Yet, section 2 of the new law included a series of restrictions that resembled the former censorship criteria. In addition, special attention was given to the role of the editor, who was now also liable to sanctions and criminal prosecution. As a consequence, many editors voluntarily submitted works to the authorities in order to confirm their suitability for publication. Scholars have pointed out that the new law was in fact a legal hoax allowing the regime to maintain repression under the guise of a revised policy. A poll conducted by Manuel Abellán in 1974 proved that, as a result of this new law, self-censorship became a common practice among nearly one quarter of the writers surveyed, and almost none of them dared to express their political opinions in their works. Similarly, editors started to carry out their own censorship programme in the form of editorial practices before submitting the work to the authorities. 


\section{BIBLIOGRAPHY}

Abellán, M. L., Censura y creación literaria en España (1939-1976), Barcelona : Ediciones Península, 1980.

Aguilar Fernández, P., Memory and Amnesia: The Role of the Spanish Civil War in the Transition to Democracy, New York : Berghahn Books, 2002.

Morcillo A. G., Memory and Cultural History of the Spanish Civil War : Realm of Oblivion, Leiden \& Boston : Brill, 2014.

Normas generales confeccionadas por la Delegación Provincial de Huesca para las Delegaciones Comarcales dependientes de la misma regulando sus actividades de propaganda, censorship booklet for internal use, January 1944.

Reig Tapia, A., Ideología e historia : sobre la represión franquista y la Guerra Civil, Madrid : Ediciones AKAL, 1986.

Southworth, H. R., El mito de la cruzada de Franco. Crítica bibliográfica, Paris : Ruedo ibérico, 1963.

\section{AUTHOR}

\section{GUILLERMO SANZ GALLEGO}

Ghent University 